\title{
Politician Control, Agency Problems, and Ownership Reform: Evidence from China*
}

\author{
Lixin Colin $\mathrm{Xu}^{\dagger}$ \\ Development Research Group \\ The World Bank
}

Tian Zhu

Division of Social Science

Hong Kong University of Science and Technology

\author{
Yi-min Lin \\ Division of Social Science \\ Hong Kong University of Science and Technology
}

June 2002

\footnotetext{
* The research for this paper was funded by a grant from the Hong Kong Research Grants Council (RGC.HKUST.6053/98H). We thank George Clarke, Bob Cull and Mary Shirley for their very helpful comments on an early version of the paper. The findings, interpretations, and conclusions in the paper are entirely those of the authors and do not necessarily reflect the views of the World Bank, its Executive Directors, or the countries they represent.

† Corresponding author. MC 3-420, Development Research Group, The World Bank, 1818 H Street, N.W., Washington, DC 20433. Phone: (202) 473-4664. Fax: (202) 522-1155. Email: Lxu1@ @orldbank.org.
} 


\title{
Politician Control, Agency Problems, and Ownership Reform: Evidence from China
}

\begin{abstract}
Using data from a recent national survey of the ownership reform of state-owned enterprises in China, we study the effects of politician control and agency problems on the performance of the reformed firms. Taking into account of the endogenous nature of the reform, we find that firm performance is positively affected by the lessening of politician control through increasing the firm's flexibility in labor deployment and by the mitigation of agency costs through introducing more effective corporate governance mechanisms such as one-share one-vote and shareholding-based composition of board structure. Ownership structure also matters to performance: relative to shareholding by the state, foreign ownership has a positive effect, individual (including employee) shareholding has a negative effect, whereas the effect of collective and legal person shareholding is indistinguishable from state shareholding. Somewhat surprisingly, business autonomy (except for labor decision autonomy) has a negative effect on performance, indicating serious agency problems in the reformed enterprises.
\end{abstract}

JEL Classification: P21, P31, D23

Keywords: ownership reform, politician control, agency problems, state-owned enterprises, corporate governance. 


\section{Introduction}

The performance of state-owned enterprises (SOEs) suffers from both political costs (i.e. the costs associated with control of firms by politicians who have political goals that differ from economic efficiency) and agency costs (i.e. the costs resulting from managerial pursuit of private benefits at the expense of the firm) (Shleifer and Vishny, 1994; Qian, 1996). Whether these costs can be contained is the key to the success of SOE reform. The large-scale ownership and organizational reform of Chinese SOEs during the second half of the 1990s represents the Chinese government's attempts to address the issues of politician control and agency problems.

From the early 1990s, China has shifted the focus of its reform of SOEs from delegation of decision-making authority to the reform of ownership and corporate governance. Two strategies have been adopted: privatization and corporatization (Zhu, 1999). ${ }^{1}$ The reform was propelled by the fact that SOEs' financial performance steadily deteriorated during the 1990s after a period of improved productivity in the 1980s (Lardy,

\footnotetext{
${ }^{1}$ Researchers appear to have different definitions of privatization and corporatization. Sometimes any divestiture of state share is taken to imply privatization. Here, we follow the World Bank (1995) and Shirley (1999) who define privatization as "the sale of state-owned assets" such that "management control (measured as the right to appoint the managers and board of directors) passes to private investors". Corporatization, on the other hand, is defined as diversification of ownership structure, especially through inclusion of non-state parties as shareholders, "to make SOEs operate as if they were private firms facing a competitive market or, if monopolies, efficient regulation" (Shirley 1999, p. 115).
} 
1998). ${ }^{2}$ Privatization is mostly used to sell some small SOEs to private entrepreneurs (Cao, Qian and Weingast, 1999). The main strategy, however, is corporatization. This is intended to transform most SOEs into three types of shareholding companies: limited liability companies (LLCs), limited liability stock companies (LLSCs), and employee-owned stock cooperatives (EOSCs) (Lin and Zhu, 2001). ${ }^{3}$ A reformed firm's shares are classified into five categories: state-owned, legal-person-owned (i.e., shares owned by any institution that has a legal person status such as an investment company), individual-owned, collective-

\footnotetext{
${ }^{2}$ Small-scale ownership reform of SOEs, which is often referred to as shareholding reform in China, began in the mid-1980s; systematic experimentation with the shareholding system began in 1992 (SCESR 1997). In December 1993, the Company Law was passed, and SOE reform entered a stage in which privatization or corporatization of SOEs could, in principle, be guided by law. Large-scale ownership reform started in the mid-1990s. By the end of 1998 , some 24,000 or $10.1 \%$ of SOEs had either been privatized or corporatized (People’s Daily, August 7, 1999).

${ }^{3}$ As reported in Lin and Zhu (2001), the vast majority of reformed SOEs were converted into these organizational forms, and only $7 \%$ were turned into pure private firms. Yet there are also a number of corporatized enterprises where non-state owners held the majority of shares. According to the Company Law, the main differences between limited liability companies and limited liability stock companies lie in the following: (i) the threshold of equity capital (0.5 million vs. 10 million yuan), (ii) the level of approving authority (sub-provincial vs. provincial government or an authority designated by the State Council), (iii) the number of shareholders (2-49 vs. 5 or above), and (iv) the liquidity of shares--only shares in the latter can be traded on a stock exchange, and only companies with equity capital of over 50 million yuan are eligible for listing. Employee-owned stock cooperatives are limited liability entities owned wholly or predominantly by the employees, individually (through shares issued to individuals) or collectively (through "collective shares"). There is no minimum equity capital requirement. The shares for individual holdings can only be issued to enterprise employees, who may receive dividends in addition to their regular wages.
} 
owned, and foreign-owned.

Corporatization aims to turn SOEs from sole state proprietorships controlled by industry-specific government agencies at various administrative levels to modern-form corporations with a Western-style corporate governance structure without serious erosion of dominant public, but not necessarily state, ownership. In most corporatized enterprises, the majority of shares are held by the state, large business entities controlled or fully owned by the state, and employees. In view of the fact that it is impossible for financially constrained private entrepreneurs to take on large stakes in significant numbers of SOEs, some degree of public ownership in corporatized enterprises is to be expected in the early stage of reform, even without ideological constraints on private ownership of enterprises.

In this paper, we use data from a recent national survey of the ownership reform of state-owned industrial enterprises in China to study the effects of politician control and agency problems on the performance of reformed enterprises. Taking into account of the endogenous nature of the reform, we find that firm performance is positively affected by the lessening of politician control through increasing the firm's flexibility in labor deployment and by the mitigation of agency costs through introducing more effective corporate governance mechanisms such as one-share one-vote and shareholding-based composition of board structure. Ownership structure also matters to performance: relative to shareholding by the state, foreign ownership has a positive effect, individual (including employee) shareholding has a negative effect, whereas the effect of collective and legal person shareholding is indistinguishable from state shareholding. Somewhat surprisingly, business autonomy (except for labor decision autonomy) has a negative effect on 
performance, indicating serious agency problems in the reformed enterprises.

Our study contributes to the literature on comparative economic transition. Chinese reform of SOEs contrasts with the reform strategy in many Central and Eastern European countries. In these countries, outright privatization is the dominant measure of enterprise reform, ${ }^{4}$ whereas in China, privatization is limited only to small-sized SOEs. It also contrasts with corporatization in these countries, where it was used to convert SOEs into wholly state-owned joint stock or limited liability companies and was pursued as a prelude to privatization (Frydman et al., 1993). ${ }^{5}$ In China, corporatization has been pursued as a lasting measure of SOE reform and, in most cases, there are non-governmental shareholders in corporatized enterprises. Previous empirical studies of the effects of enterprise reform in China have focused on the effect of decentralization of decisionmaking authority and incentive contracting on the performance (technical efficiency in particular) of SOEs (Groves et al., 1994; Jefferson, Rawski and Zheng, 1996; Li 1997; Xu, 2000; Shirley and $\mathrm{Xu}, 2001$ ), or compare differences in performance between state and non-state firms (Woo et al., 1994; Xu, 1995; Jefferson, Rawski and Zheng, 1996; Zhang, Zhang and Zhao, 2001). This paper is, to our knowledge, the first systematic empirical

\footnotetext{
${ }^{4}$ The results of privatization in these countries are mixed. See Megginson and Netter (2001) for an excellent comprehensive survey of empirical studies on privatization.

5 Actual privatization, however, took place at a much slower pace than expected. Consequently, state enterprises were simply left on their own with very little supervision from the state. Both the managers and the governing bodies of state properties engaged extensively in corruption and rent-seeking behavior (Dobrinsky 1996; Frydman et al 1993).
} 
study of the impact of the more recent ownership reform of SOEs, the most important reform measure in the past decade.

Our study also adds empirical material to the literature on corporatization. While there is a large body of literature on privatization (Megginson and Netter, 2001), there has been only limited empirical research to systematically evaluate corporatization, in China or elsewhere. Lin and Zhu (2001) use the same survey data set mainly to examine organizational forms, ownership and corporate governance structure of reformed enterprises, and the determinants of the pace of the reform. In this paper, we focus on the determinants of post-reform operating performance and perceived effects of the reform. Lee (1999) finds that reforms with corporatizing elements in China during 1980-1994 lowered wages and improved productivity. Our study complements his in focusing on a different time period, contents of reforms, and the use of a different conceptual framework. Finally, Shirley (1999) provides empirical evidence that corporatization works better when combined with ownership and other reforms. The evidence she provides is based on case studies of 12 developing countries. In this paper, we use a large sample of firms from a national survey in China to examine the short-run impact of ownership reform, particularly corporatization, on performance. In particular, we focus on the role of decision-making rights, ownership structure, and corporate governance in explaining the post-reform performance of firms.

In section 2, we present a conceptual framework that will be used to guide our analysis and to interpret our empirical findings. In section 3, we describe the data and define the dependent and explanatory variables. Section 4 presents the econometric 
methods. The findings are reported in section 5. The concluding section 6 summarizes the main results and discusses their implications as well as limitations.

\section{Politician Control, Agency Problems, and Corporate Governance}

Our empirical investigation is guided by some of the recent economic theories of organization and corporate governance, where authority relations are a central issue. Aghion and Tirole (1997) further distinguish between formal and real authority in economic organizations. They show that real authority, i.e., the effective control over decisions, is determined by the structure of information, which in turn depends on the allocation of formal authority (i.e., the rights to decide). In other words, if an agent is allocated with more formal authority, he will have incentives to acquire more productive information and hence enjoy more real authority. However, agency costs increase as more formal authority is delegated to the agent.

Chinese SOEs before economic reform were controlled by politicians, ${ }^{6}$ who had almost all the formal authority as well as most of the real authority over business and personnel decisions. Such an allocation of authority led on one hand to a lack of

\footnotetext{
${ }^{6}$ We follow Shleifer and Vishny (1994) in using the term "politicians" instead of "bureaucrats", the term used by, e.g., Bai and Wang (1998), Li (1998) and Shirley (1999), to refer to government officials in charge of enterprises in a socialist or transition economy. This terminology is consistent with our using the term "political costs" rather than "bureaucracy costs" to refer to inefficiencies associated with politician control. In organizational economics, the term "bureaucracy costs" is often used to refer to the costs of using hierarchies rather than markets in organizing transactions (Williamson, 1985).
} 
managerial initiatives, and politically-motivated or misinformed business decisions on the other. Politicians have incentives to control or/and subsidize SOEs to achieve economically inefficient objectives for political purposes. In particular, politicians may require an SOE to hire more workers than needed to increase employment, or to maintain excess employment even when a firm's performance declines (Shleifer and Vishny, 1994). Politicians do so in order to win political support, or to avoid "social instability" that may arise as a result of high unemployment. Politicians may ask an SOE to meet output growth targets that they can tout as their policy achievement even if the enterprise cannot sell all of its output at a profit. These considerations led to many problems among Chinese SOEs under the old system.

Chinese reform that delegated many of the decision-making rights to SOE managers in the 1980s (Naughton, 1995) can be viewed as allocating some of the formal authority to the managers. As implied by Aghion and Tirole's theory, managerial autonomy then motivated SOE managers to become more informative about business decisions; as a result, they enjoyed more real authority. However, as agents of the state, SOE managers have a strong incentive to use (i.e., abuse) their newly acquired power in their own self-interest. On the other hand, politicians still maintained formal authority over key personnel, asset deployment and investment decisions.

In an insightful application of the organization theories to Chinese enterprise reform, Qian (1996) characterizes the plight of Chinese SOEs in the 1990s as being caused by a combination of agency problems and politician control. Agency problems arise as managers enjoy more authority, formal as well as real, over business decisions thanks to 
the delegation reforms. A primary example of agency costs is asset stripping. While politician control may be a mechanism of checks-and-balances to mitigate agency costs, it also causes the loss of information, inefficient interference in management, use of incompetent but obedient managers, bad investment decisions, and soft budget constraints. ${ }^{7}$ Qian (1996) argues that SOE reform should aim at reducing both political and agency costs by establishing a new corporate governance system through a variety of measures such as depoliticization, privatization, and corporatization.

China's recent ownership reform is indeed intended to deal with both of these costs through the establishment of a Western-style corporate system. It is hoped that political costs and agency costs will be simultaneously reduced by separating government from enterprises, introducing non-government corporate/institutional shareholders as well as employee and private shareholders, and establishing an effective corporate governance structure.

However, as state ownership is still significant in the majority of reformed enterprises and social institutions such as a social safety net that may be necessary for the complete separation of the government from enterprises have just begun to develop in China, some degree of politician control should still linger in the reformed firms.

\footnotetext{
${ }^{7}$ Bai and Wang (1998) view politician control (or bureaucratic control in their paper) as a form of agency problems because politicians enjoy the control rights but are not the residual claimants and thus can be viewed as agents of the citizens. They show that bureaucratic control leads to the persistence of the softbudget constraint in the state sector. In this paper, we follow Qian (1996) in using the term "agency problems" in a narrow sense to refer to the managerial moral hazard problem.
} 
Moreover, it takes time to establish market-oriented economic and legal institutions that are conducive to effective corporate governance in a transitional economy (Shleifer and Vishny, 1997). Therefore, corporate governance in the reformed enterprises may deviate from what is stipulated in the law and may be quite ineffective in containing agency costs.

While theoretically both political costs and agency costs may exist in reformed enterprises, it is an empirical issue as to which costs are more detrimental to firm performance. If politician control is more detrimental than agency problems, then we would expect, ceteris paribus, firms with more decision-making autonomy after reform to exhibit better performance. Otherwise, more autonomy for managers may not necessarily be followed by improved performance.

Even if agency problems are serious, however, managerial autonomy in labor decisions, which have been significantly conditioned by political considerations, should spur more performance improvement than most other types of managerial autonomy. According to Shleifer and Vishny's theory, when politicians have direct control over the operation of SOEs, there is likely to be more labor redundancy. In fact, there is strong evidence that excess employment in Chinese SOEs was large (Dong and Putterman, 2001). Managers, on the other hand, tend to assign less weight to the political benefits from employment and greater weight to profits than politicians do. When given the control rights over labor decisions, managers have a stronger incentive to cut excess employment than politicians. Therefore, we expect managerial autonomy over labor issues to have a relatively stronger performance effect than managerial autonomy over other decisions.

Politician control also manifests itself in the selection and replacement mechanism 
of CEOs. If CEOs are appointed by the government, they are more likely to be subject to politicians' influence. Thus, if politician control is a more serious issue than agency problems, we would expect performance to be worse in firms whose CEOs are appointed by the government. Moreover, replacing the incumbent management during the reform is found in the literature to result in better firm performance (Denis and Denis, 1995) and more restructuring (Barberis et al., 1996) in transition economies.

Ownership structure is widely perceived to affect performance. ${ }^{8}$ More ownership stakes by non-state shareholders such as private individuals or foreign investors may imply relatively lower political costs, closer monitoring and more pressure for profits on selfinterested mangers. However, not all private shareholders exert equal efforts on monitoring. Since the benefits of monitoring are shared by all shareholders while the costs are borne completely by the monitoring party, large shareholders internalize to a greater extent the costs and benefits of monitoring, and therefore exert more monitoring efforts (Shleifer and Vishny, 1986). Indeed, Anderson, Lee and Murrel (2000) find that dispersed private ownership is found to lead to worse performance than state ownership in Mongolia. In our data, foreign and legal person shareholding may be characterized as representing relatively more concentrated ownership. It is thus possible that foreign ownership and legal person ownership may lead to better performance than state ownership. On the other hand, if shareholding by domestic private individuals (mostly employees in the Chinese case) is more of a dispersed ownership, then the comparison between state ownership and private

\footnotetext{
${ }^{8}$ See Shleifer (1998) and Megginson and Netter (2001) for excellent summaries of theories and evidence on the performance effect of ownership.
} 
ownership can only be settled empirically.

Theories of corporate governance imply that the degree of alignment of firm ownership and control, as reflected in the voting mechanism and the board structure, matters to performance. ${ }^{9}$ One-share-one-vote is generally believed and theoretically shown to be a more efficient voting mechanism in corporate governance (Grossman and Hart, 1988; Harris and Raviv, 1988). One-share-one-vote helps to reduce the likelihood that the manager would respond to shareholders that have greater control than their proportion of the total shares suggests. A shareholding-based board of directors provides another mechanism to protect shareholder interests. If a firm's board structure is characterized by a divergence between ownership shares and board representation, the manager and the shareholders who are disproportionately represented on the board may collude to pursue private or parochial interest at the expense of the under-represented shareholders. We thus expect, ceteris paribus, firms observing the one-share-one-vote rule and firms with a shareholding-based board structure to have better performance.

\section{Data and Variables}

The data we analyze are drawn from a national survey of the reform of industrial SOEs in China. The survey was conducted by the National Statistical Bureau of in the

\footnotetext{
${ }^{9}$ See Shleifer and Vishny (1997) for a survey of the corporate governance literature and Hermalin and Weisbach (2001) for a survey of a new literature on how the structure of the board of directors affects company performance.
} 
summer of 1998. Its aim was to examine how ownership reform had proceeded among industrial SOEs during all of 1997 and the first quarter of 1998. The survey took the form of a three-part questionnaire. The first part contains: (1) questions about the enterprise's basic profile (i.e., enterprise code, sector, location, and size); (2) the status of ownership reform (e.g., whether and when ownership reform was completed and what new organizational form was adopted, etc.); and (3) a personal profile of the top manager (e.g., age, gender, education, etc.). The second part of the questionnaire contains a set of questions about ownership structure and accounting (i.e., assets, liabilities, equity, sales, interest payment, profits, and taxes, etc.) for the period under review. The third part of the questionnaire contains questions about various aspects of the reform, including questions on corporate governance structure, enterprise autonomy and managerial turnover.

A total of 40,246 industrial enterprises responded to the survey, which was equivalent to $62 \%$ of the total number of industrial SOEs that were in operation in that year. ${ }^{10}$ All the enterprises in the survey were required to answer the first part of the questionnaire. 6,872 of the enterprises that responded to the survey (i.e., $17 \%$ of the enterprises surveyed) indicated they had completed their reform by the time of the survey. These enterprises were also required to answer the second part of the questionnaire (i.e., ownership and accounting information).

Only a selected group of reformd enterprises were required to answer the third part

\footnotetext{
${ }^{10}$ According to China Statistical Yearbook (1999, p. 421), there were about 64,900 industrial SOEs in 1998.
} 
of the questionnaire, and 2,632 of them responded. ${ }^{11}$ Out of the 2,632 selected enterprises that responded all three parts of the questionnaire, 1,634 completed their reform in 1997. We generate a dataset based on the survey results of these enterprises. We only select firms that completed their reform in 1997 because we will use the performance data in the first quarter of 1998 to examine the effect of the reform through the resulting ownership structure, corporate governance mechanisms and enterprise autonomy. The data set thus has information on the profiles of reformed enterprises and managers, accounting data and information on ownership structure for all of 1997 and the first quarter of 1998, as well as information on certain aspects of corporate governance. Due to missing values, the number of valid observations for our regression analysis is 884 , about $54 \%$ of the sample.

The variables to be used in our analysis are defined in Table 1. Our dependent variable is the conventional operating performance measure: returns on assets (ROA), defined as the ratio of before-tax profits over the book value of total assets in the first quarter of 1998. As the firms in our sample completed their reform in 1997, this measure only reflects the reform's short-term impact on performance with the underlying assumption that operating performance in the first quarter of 1998 can be explained by organizational changes brought about by the reform before 1998. We justify this

\footnotetext{
${ }^{11}$ The number of enterprises selected by each province (or centrally administered municipality) was assigned by the National Statistical Bureau and ranged from 60 to 150. The provincial statistical bureau's survey team was responsible for selecting these enterprises. While the selection at the provincial level was supposed to be random, we do not know how quality control with regard to randomness and representativeness was achieved during the sampling process.
} 
assumption by noting that the reform process takes several stages, including planning, proposal, approval and implementation, and normally lasts more than a year. The blueprint of the reform takes shape well before the completion of the actual reform. The affected parties should therefore react to the proposed reform well before it actually takes place. ${ }^{12}$

In our analysis, the effectiveness of the protection of shareholder interest is proxied by two variables. The first is a dummy variable (1share_1vote) that takes the value of one when one-share-one-vote is adopted for the shareholders meeting and zero otherwise. The second is a new measure we introduce in this paper to proxy the extent of deviation of ownership from control. Specifically, we define a variable $D_{O-B}$ that measures the divergence between the ownership structure and the structure of the board of directors:

$$
D_{O-B}=\sqrt{\sum_{j=1}^{J}\left(S_{j}^{B}-S_{j}^{O}\right)^{2}},
$$

where $S_{j}^{B}$ is the share of membership on the board of directors by each type of shareholders (including state, legal person, collective, individual and foreign); ${ }^{13}$ and $S_{j}^{O}$ is the ownership share by each type of shareholders. $D_{O-B}$ is obviously bounded between 0

\footnotetext{
${ }^{12}$ For example, if an economics department proposes a new policy that two papers published in top ranked economic journals are required for tenure, and the policy will be implemented a year later, then all nontenured faculty would adopt a strategy in response to this new policy before its implementation.

${ }^{13}$ For the board of directors' data, there is no information on the representation of the "collective" shares, which seem to be included in the vague category "others". We thus treat the "others" as an approximate measure for the "collective" shares.
} 
and $\sqrt{2}$. It turns out that this innovative measure of the separation of ownership and control, while an imperfect proxy, helps reveal an important source of variation with regard to the determinants of firm performance. Based on earlier discussions, we expect $D_{O-B}$ to be negatively related to performance and 1share_lvote to be positively related to performance.

\section{Methods}

The regression we run is the following:

$$
R O A_{i}=X_{i} \beta_{2}+A_{i} \alpha_{2}+O_{i} \gamma_{2}+D_{O-B, i} \delta_{2}+C_{i} \theta_{2}+\varepsilon_{2 i}
$$

$X$ includes such conventional controls as leverage (lagged by one period), and log of the number of employees (lagged by one period) as a measure of size. We have also tried including the logarithm of capital (lagged by one period) in $X$, and the results remain very similar to without including it, while the adjusted $\mathrm{R}$ square is roughly the same, and we thus decided not to include it. $A$ includes two autonomy dummies. The first is a dummy variable (autonomy) indicating whether the CEO has basic decision-making autonomy (the default is that the CEO had limited autonomy). The second is a dummy variable (l_flex) indicating whether the CEO has flexibility in deploying labor after the reform. $O$ includes the percentage ownership share by legal persons, collectives, individuals, and foreigners, respectively, with the omitted category being the state share. Finally, $C$ includes a dummy (staying_CEO) indicating whether the incumbent CEO stayed on after the reform, and a dummy (CEO_by_govt) that takes the value of one if the post-reform CEO is appointed by 
the government, and zero otherwise (when the CEO was appointed by the firm, board of directors or shareholder meetings).

We shall first estimate equation (2) with ordinary least square method. However, we recognize that the reform variables (i.e., $A, O, D$ and $C$ ) could be endogenous in three senses. First, there could be reverse causality. That is, instead of reform characteristics affecting performance, it could be performance causing the firm to choose systematically different reform actions. Second, there could be selection bias, that is, certain types of firms choose particular package of reform actions. In other words, firm heterogeneity could be correlated with both performance and reform actions. Finally, there is the classical omitted-variable bias. Omitted variables could be correlated with both performance and the reform variables. When examining the effects of reforms on performance, the transition literature has paid attention to the endogeneity issue (Frydman, Gray, Hessel, and Rapaczynski, 1999; Anderson, Lee and Murrell, 2000; Li, 1997; Shirley and Xu, 2001).

We deal with the endogeneity issue by identifying some special features characterizing the Chinese reform processes. First, one ingredient of the latest wave of Chinese SOE reforms is to "grab the big and let go the small". Chinese SOEs were classified as large, medium, and small, often based on historical heritage rather than current size. The three historically-determined size categories, i.e., large, medium, and small size, qualify as instruments. That is, the government might adopt different reform policies according to the historically determined size, while these size indicators should not affect performance, especially since we have controlled for the number of employees of the firm. Second, the control benefits of different industries to the government might be 
different. The line ministries might face different incentives to reform SOEs. As a result, the reforms actions of a firm might be heavily influenced by industry affiliation. Third, reform actions might be determined by the approving authority of the reform, which included State Economic and Trade Commission (state ETC), provincial ETCs, local ETCs, State System Reform Committee (state SRC), provincial SRCs, local SRCs, other governing authority of the firm, multiple government agencies (for joint decisions), and the ad hoc agency in charge of ownership reform. The difference in the approving authority appears to matter to the reform packages that were adopted, yet it is not directly related to firm performance.

In our implementation, for each potentially endogenous variable, say, A, we first obtain the fitted values of A on (a) the three size dummies, industry dummies (and we call the fitted value $\left.A_{\text {size, industry }}\right)$ and (b) the reform approving agency dummies $\left(A_{\text {agency }}\right) . A_{\text {size, }}$, industry can be interpreted as the target reform actions from the central government and line ministries, while $\mathrm{A}_{\text {agency }}$ approximates the reform approving agency's specific reform target. These two variables therefore reflect the reform policies of the policy suppliers (i.e., the government), and should be correlated with firm-specific reform actions, while likely being un-correlated with firm-specific performance. We shall present estimations based on generalized-methods-of-moments that treat all the reform actions as endogenous, and use $A_{\text {agency }}, A_{\text {size,industry }}$ to identify the effects of these actions.

It is hard to preclude the possibility that those potential instruments might also be correlated with the performance, in which case they would serve as poor instruments. To examine the validity of our identifying assumptions, we shall rely on the over-identifying 
restrictions test. As we shall see, the statistical tests suggest that these instruments serve as valid instruments.

\section{Results}

\section{Descriptive Statistics}

Descriptive statistics of the dependent and explanatory variables used in our regression analysis are presented in Table 1. Some interesting facts stand out. On average, the ROA in the first quarter of 1998 was only $0.3 \%$--translated into an annual figure of $1.2 \%$--reflecting the troubles still faced by many of the firms after ownership reform. The vast majority of firms appear to have decision-making autonomy after reform (90\%), but the grant of autonomy on labor issues to managers lags behind (70\%), reflecting the government's concerns over the unemployment of SOE workers. The measure of the divergence between ownership and board control is fairly big (0.5), as the perfect alignment of ownership and control implies a value of zero for the variable. It appears that the majority of incumbent CEOs stay on after reform (63\%), and roughly $17 \%$ of the CEOs are appointed directly by the government. The one-share-one-vote principle is observed by only one third of the firms. On average, the state remains the largest shareholder, accounting for roughly $48 \%$ of total shares in reformed enterprises. Legal-person share accounts for $14 \%$. However, there is also substantial private involvement: $31 \%$ of the total shares of those former SOEs are in the hands of private citizens, and $1.3 \%$ are owned by foreigners. The remaining shares are held by collectives. 


\section{Base Results}

Table 2 presents the base results with column (1) for the OLS results and (2) for GMM results. Before getting to the performance determinants of our main interest, we first examine how some conventional factors affect our performance measures. When the endogeneity is not considered in Column (1), firm size is not correlated with ROA, and firms burdened with more debts exhibit worse operating performance. However, once endogeneity is considered in Column (2), the association between operating performance and leverage disappears but firm size has a small but significant adverse effect on performance.

Now we examine how business autonomy, ownership structure and corporate governance affect firm performance after reform. Autonomy does not have significant correlation with performance in the OLS regression. Taking into account the endogeneity of the reform dramatically changes our conclusion. Now autonomy is associated with a significant drop in performance. Recall that political costs would imply a positive effects of autonomy on performance, while agency costs would mean a negative effects. We thus interpret the negative effect of autonomy on performance as implying the dominance of agency costs over political costs under those particular decision rights captured by autonomy. Consistent with our conjecture, autonomy over labor issues ( $l_{-}$flex) has a significant positive correlation with operating performance whether we consider endogeneity or not. But note that the magnitude of the effect is far greater when endogeneity is taken into consideration. This result suggests that $l$ flex is negatively correlated with error term, implying that firms with worse performance were granted more 
labor discretion, and correcting for such selection effects raise our estimates of the importance of $l$ flex. The coefficient in the GMM regression suggests that granting autonomy in labor decision would increase annualized ROA by $8.4 \%$ (i.e., $4 * 0.021$ ) instead of $2.8 \%$ in the OLS regression. The result is consistent with our conjecture that political costs associated with labor issues are especially large, and autonomy over labor deployment is especially important for efficiency improvement.

Ownership structure has important effects on performance, and the contrast between the first and second column of Table 2 is striking. When ownership variables are treated as exogenous, then, relative to state owners, legal person ownership had a positive and statistically significant relation with performance. The correlations of performance with either individual ownership or foreign ownership are totally insignificant. When ownership variables and other reform variables are considered endogenous, however, the results change completely. The effect of legal-person ownership becomes statistically indistinguishable from state ownership. Since legal-person ownership tends to be state ownership in another form, this result is more intuitive than the OLS result. The effect of private individual ownership now is negative and statistically significant. This result is consistent with the notion that private ownership by itself is not sufficient to counter agency costs; some kind of concentrated private ownership would be needed to achieve effective monitoring (Shleifer and Vishny, 1986). In other words, state ownership in theory represent nominally the ownership of all the people, but at least some delegated agency (the bureaucrats or politicians) should be accountable. Yet in the case of dispersed private ownership, there is still the nominal ownership by many people but without the benefits of some accountability. Our finding on the negative effect on performance of dispersed 
private ownership is also consistent with evidence from Mongolia in Anderson, Lee and Murrell (2000), who find similar evidence after considering the endogeneity of the ownership structure. Another interesting finding is the effect of foreign ownership becomes positive and statistically significant. The magnitude of the effect is also large: an increase of foreign ownership share by 10 percent would raise annualized ROA by more than 3 percentage points (i.e., $4 * 0.1 * 0.076$ ).

The results on CEO appointment and turnover also change dramatically when considering endogeneity. When not considering endogeneity, firms whose CEOs were appointed by the government had lower performance, and firms with the same CEO after reform were more likely to have better performance. Once we take into consideration of endogeneity, however, CEO appointment by the government no longer has any systematic relationship to performance. Moreover, incumbent CEOs are associated with negative (although statistically insignificant) instead of the above mentioned positive performance effect. This suggests a positive nature of selection bias: CEOs chose to stay in firms with better performance. The negative effect of CEOs staying is weakly consistent with another interesting hypothesis: managerial turnover leads to new and likely better human capital or more credible threat of punishment for managerial shirking for the decision makers in the firm, and hence improving performance. This result is weakly consistent with the finding in the literature that changing CEOs results in better performance (Denis and Denis, 1995) and more reform (Barberis et al., 1996) in transition economies.

The voting mechanism for shareholder meetings also matters. The one-share-onevote dummy has a somewhat positive and but insignificant effect on performance when not 
considering endogeneity, but its positive effect on performance becomes stronger and statistically significant once we take into account endogeneity.

Finally, consistent with our hypothesis, the deviation of board structure from share ownership has a significant and negative effect on performance. The effect that takes into account of endogeneity is stronger than in the OLS regression. The magnitude of effect is very large. For example, compared with firms in which there is hypothetically no such deviation (i.e., $D_{O-B}=0$ ), firms with the maximum divergence between ownership and control $\left(D_{O-B}=\sqrt{2}\right)$ would have an annualized ROA that is 14 percentage points lower.

\section{Robustness Check}

It is possible that the effects of decision-making autonomy, ownership structure and corporate governance mechanisms differ qualitatively among the three main organizational types, i.e., limited liability stock companies (LLSCs), limited liability companies (LLCs) and employee-owned stock cooperatives (EOSCs). It would be re-assuring to find that most of our key findings stay intact for each of these organizational types. Table 3 presents the results separately for each of the three organization types. We present both the OLS and GMM results. Indeed, in the majority of the cases for our important variables, the signs remain intact across the sub-samples. A notable difference is in the case of LLSC, which is normally a bigger and more formal organization than the other two types. In the GMM regression for the subsample of LLSCs, ownership shares by legal persons or collectives have a postive effective on performance relative to state-owned shares, whereas individual or foreign ownership shares have no distinguishable effect on performance from state shares. 
We have also experimented with including other potential determinants of performance and found that they do not matter much. ${ }^{14}$ In particular, we find that the following factors in general do not have a statistically significant effect on our dependent variables: (i) how the board of directors is appointed (by shareholder meeting, by the government, by the CEO, by the firm with the government's approval, or by "other methods"); (ii) the authority approving the reform (central, provincial, or lower level government); (iii) whether the CEO is also the chairman of the board; and (iv) the size of the board. We experimented with (iii) as a determinant of performance because there has been a concern in China about the independence of the board when the CEO is also the chairman. We tried (iv) because the literature seems to suggest that board size is negatively correlated with performance (Hermalin and Weisbach, 2001). The argument is that large board size suffers from the free-rider problem in the board's monitoring of the CEO and exercising of control over key business decisions. Our result offers neither strong rejection nor strong confirmation for the hypothesis. In particular, the effect of the logarithm of board size is negative but highly insignificant in the pooled sample; but it is negative and close to being statistically significant in the sample of LLCs, the most popular organization form.

\section{Conclusions}

Using a large sample of Chinese firms undergoing ownership reform in 1997, we examine the effectiveness of various means to counter political and agency costs in reformed enterprises. We find evidence that firms tend to perform better when the

\footnotetext{
${ }^{14}$ The experiments mentioned in this paragraph were conducted with the OLS specification.
} 
managers have decision-making autonomy over labor deployment, when ownership and control are in better alignment, and when foreign ownership stake is higher. Interestingly, dispersed private ownership leads to worse performance than even state ownership, suggesting the seriousness of the free-rider problem in monitoring.

Our analysis suggests that it is important to take into account the endogenous nature of the ownership reform. Indeed, many of the results change directions when the endogenous nature is taken into account in empirical implementation. It is also worth noting that some of the factors conventionally thought to be important for performance, such as the size of the board, how board members are appointed, whether the CEO is appointed by the government, and whether the CEO also acts as the chairman of the board, do not have a significant impact. Overall, our study of the recent experience of Chinese enterprise reform suggests that differences in authority allocation, ownership structure, and corporate governance mechanisms hold important clues to explaining performance variation in reformed firms.

The findings in this paper, however, are subject to important caveats. First, the short-term ROA is not an ideal measure of the reform outcome. The long-term effects of ownership reform need to be explored in future research. Second, the data is crosssectional, and thus we have no means of controlling for firm heterogeneity. Since both flaws are due to the limitations of the data set, the collection of better quality data is needed to improve our understanding of the issue.

These limitations notwithstanding, one should not take lightly the empirical regularities found in our analysis, especially because we are able to find reasonably good 
instruments (judged both by a priori reasoning and statistical tests) for the various reform actions. Most of our findings are consistent with what is implied by theory and with findings in other related empirical studies (Megginson and Netter, 2001), and thus should be given credence.

\section{References}

Aghion, Philippe, and Jean Tirole. 1997. "Formal and Real Authority," Journal of Political Economy, 105 (1), 1-29.

Anderson, James H., Young Lee, and Peter Murrell. 2000. "Competition and Privatization Amidst Weak Institutions: Evidence from Mongolia,” Economic Inquiry, 38 (4), $527-49$.

Bai, Chong-en, and Yijiang Wang. 1998. "Bureaucratic Control and the Soft Budget Constraint," Journal of Comparative Economics, 26(1), 41-61.

Barberis, Nicholas, Maxim Boycko, Andrei Shleifer, and Natalia Tsukanova. 1996. "How does Privatization Work? Evidence from the Russian Shops," Journal of Political Economy, 104, 764-790.

Cao, Yuanzheng, Yingyi Qian, and Barry R. Weingast. 1999. "From Federalism, Chinese Style to Privatization, Chinese Style," Economics of Transition, 7(1), 103-131.

Denis, David J., and Diane K. Denis. 1995. "Performance Changes Following Top Management Dismissal," Journal of Finance, 50, 1029-1057. 
Dobrinsky, Rumen. 1996. "Enterprise Restructuring and Adjustment in the Transition to Market Economy: Lessons from the Experience of Central and Eastern Europe," Economics of Transition, 4(2), 389-410.

Dong, Xiao-yuan, and Louis Putterman. 2001. "Soft Budget Constraints, Social Burdens, and Labor Redundancy in China's State Industry," mimeo, University of Winnipeg.

Frydman, R., A. Rapaczynski, and J. Earle. 1993. The Privatization Process in Central Europe. London: Central European University Press.

Greeene, William H. 1997. Econometric Analysis. Upper Saddle River, NJ.: Pretince Hall, third edition.

Groves, Theodore, Yongmiao Hong, John McMillan, and Barry Naughton. 1994. "Autonomy and Incentives in Chinese State Enterprises," Quarterly Journal of Economics, 109(1), 183-209.

Groves, Theodore, Yongmiao Hong, John McMillan, and Barry Naughton. 1995. "China's Evolving Managerial Labor Market," Journal of Political Economy, 103, 873-892.

Grossman, Sanford, and Oliver Hart. 1988. "One Share-One Vote and the Market for Corporate Control," Journal of Financial Economics, 175-202.

Harris, Milton, and Artur Raviv. 1988. "Corporate Governance: Voting Rights and Majority Rules," Journal of Financial Economics, 203-235.

Hermalin, Benjamin E., and Michael S. Weisbach. 2001. "Boards of Directors as an Endogenously Determined Institution: A Survey of the Economic Literature," 
NBER working paper 8161.

Jefferson, Gary H., Thomas G. Rawski, and Yuxin Zheng. 1996. "Chinese Industrial Productivity: Trends, Measurement Issues, and Recent Developments," Journal of Comparative Economics, 23(2), 146-180.

Lardy, Nicholas. 1998. China's Unfinished Economic Revolution. Washington, DC: Brookings Institution Press.

Lee, Young. 1999. "Wages and Employment in China's SOEs, 1980-1994: Corporatization, Market Development, and Insider Forces," Journal of Comparative Economics, 27, 702-29.

Li, David D. 1998. "Changing Incentives of the Chinese Bureaucracy," American Economic Review, 88(2), 393-397.

Li, Wei. 1997. "The Impact of Economic Reform on the Performance of Chinese State Enterprises, 1980-1989", Journal of Political Economy, 105(5), 1080-1106.

Lin, Yi-min, and Tian Zhu. 2001. "Ownership Restructuring in Chinese State Industry: An Analysis of Evidence on Initial Organizational Changes," China Quarterly, 166, 305-341.

Megginson, William L., and Jeffry M. Netter. 2001. "From State to Market: A Survey of Empirical Studies on Privatization," Journal of Economic Literature, 39(2), 321389.

Naughton, Barry. 1995. Growing Out of the Plan: Chinese Economic Reform, 1978-1993. 
New York: Cambridge University Press.

Qian, Yingyi. 1996. "Enterprise Reform in China: Agency Problems and Political Control," Economics of Transition, 4(2), 422-447.

SCESR (State Commission for Economic System Reform). 1997. Qiye Gufenzhi Gaizao Yu Zichan Chongzu Fangan, [Schemes for Enterprise Shareholding Reform and Asset Reorganization], Beijing: China Commerce Press.

Shirley, Mary, and Lixin Colin Xu. 2001. "The Empirical Effects of Performance Contracts," Journal of Law, Economics, and Organization, 17(1), 168-200.

Shirley, Mary. 1999. "Bureaucrats in Business: The Roles of Privatization versus Corporatization in State-Owned Enterprise Reform," World Development, 27, 11536.

Shleifer, Andrei. 1998. "State versus Private Ownership," Journal of Economic Perspectives, 12(4), 133-150.

Shleifer, Andrei, and Robert W. Vishny. 1986. "Large shareholders and corporate control," Journal of Political Economy 94, 461-488.

Shleifer, Andrei, and Robert W. Vishny. 1994. "Politicians and Firms," Quarterly Journal of Economics, 109(4), 995-1025.

Shleifer, Andrei, and Robert W. Vishny. 1997. "A Survey of Corporate Governance," Journal of Finance, 52(2), 737-783.

Williamson, Oliver E. 1985. The Economic Institutions of Capitalism, New York: The Free 
Press.

Woo, Wing Thye, Wen Hai, Yibiao Jin, and Gang Fan. 1994. "How Successful Has Chinese Enterprise Reform Been? Pitfalls in Opposite Biases and Focus," Journal of Comparative Economics, 18(3), 410-437.

World Bank. 1995. Bureaucrats in Business. New York: Oxford University Press.

Xu, Chenggang. 1995. A Different Transition Path: Ownership, Performance, and Influence of Chinese Rural Industrial Enterprises, New York and London: Garland.

Xu, Lixin Colin. 2000. "Control, Incentives, and Competition: The Impact of Reform in Chinese State-Owned Enterprises," Economics of Transition, 8(1), 151-173.

Zhang, Anming, Yimin Zhang, and Ronald Zhao. 2001. "Impact of Ownership and Competition on the Productivity of Chinese Enterprises," Journal of Comparative Economics, 29, 327-346.

Zhu, Tian. 1999. "China's Corporatization Drive: An Evaluation and Policy Implications," Contemporary Economic Policy, 17(4), 530-539. 
Table 1. Variable Definitions and Descriptive Statistics

\begin{tabular}{|c|c|c|c|}
\hline Variable & $\underline{\text { Definition }}$ & $\underline{\text { Mean }}$ & $\underline{\text { S.D. }}$ \\
\hline$R O A$ & $\begin{array}{l}\text { Returns on assets, defined as before-tax profits over the book value of total } \\
\text { assets for the first quarter of } 1998 \text {. Since the top and bottom } 1 \text { percents } \\
\text { represent significant outliers, we winsorized the data at the } 1 \text { and } 99 \\
\text { percentiles. That is, the top and bottom } 1 \text { percents are replaced with } 99^{\text {th }} \text { and } \\
1^{\text {st }} \text { percentile values, respectively. }\end{array}$ & 0.003 & 0.029 \\
\hline leverage $_{t-1}$ & Debt-equity ratio in 1997 . Winsorized at 1 and $99^{\text {th }}$ percentiles. & 0.822 & 1.259 \\
\hline $\ln L_{t-1}$ & The logarithm of the number of employees in 1997. & 8.917 & 2.127 \\
\hline autonomy & $\begin{array}{l}\text { A dummy variable that is one when the manager of the reformed firm has } \\
\text { complete or basic autonomy over operating decisions and zero otherwise. }\end{array}$ & 0.901 & 0.299 \\
\hline l_flex & $\begin{array}{l}\text { A dummy variable that is one when the manager feels that he or she has } \\
\text { reasonable flexibility and discretion in labor deployment. }\end{array}$ & 0.704 & 0.457 \\
\hline$D_{O-B}$ & $\begin{array}{l}\text { A measure of the divergence between ownership structure and board } \\
\text { structure, constructed as } D_{O-B}=\sqrt{\sum_{j=1}^{J}\left(S_{j}^{B}-S_{j}^{O}\right)^{2}} \text {, where } S_{j}^{B} \text { is the share of } \\
\text { membership on the board of directors by each type of shareholders, } S_{j}^{O} \text { is } \\
\text { the percentage share of ownership, and } j=\text { state, legal person, collective, } \\
\text { individual, and foreign. }\end{array}$ & 0.500 & 0.432 \\
\hline staying_CEO & $\begin{array}{l}\text { A dummy variable that is one when the pre-reform CEO stays on as the CEO } \\
\text { after reform. }\end{array}$ & 0.631 & 0.483 \\
\hline CEO_by_govt & $\begin{array}{l}\text { A dummy variable that is one when the post-reform CEO is appointed by the } \\
\text { government. }\end{array}$ & 0.171 & 0.376 \\
\hline 1share_lvote & $\begin{array}{l}\text { A dummy variable that is one when the one-share-one-vote principle is } \\
\text { adopted for the shareholder meetings. }\end{array}$ & 0.327 & 0.469 \\
\hline share_legal_person & The share of state ownership in total outstanding shares in 1998. & 0.143 & 0.298 \\
\hline share_individual & The share of individual ownership in total outstanding shares in 1998. & 0.312 & 0.380 \\
\hline share_foreign & The share of foreign ownership in total outstanding shares in 1998. & 0.013 & 0.081 \\
\hline
\end{tabular}


Table 2. Determinants of Firm Performance (ROA): Pooled Sample

\begin{tabular}{|c|c|c|}
\hline & $\begin{array}{l}(1) \\
\text { OLS }\end{array}$ & $\begin{array}{c}(2) \\
\text { GMM }\end{array}$ \\
\hline \multirow[t]{2}{*}{$\ln L_{t-1}$} & 0.000 & -0.001 \\
\hline & $(0.35)$ & $(2.12)^{\star \star}$ \\
\hline \multirow[t]{2}{*}{ leverage $_{t-1}$} & -0.002 & -0.000 \\
\hline & $(2.17)^{\star \star}$ & $(0.04)$ \\
\hline \multirow[t]{2}{*}{ autonomy } & 0.004 & -0.034 \\
\hline & $(1.24)$ & $(1.89)^{*}$ \\
\hline \multirow[t]{2}{*}{ l_flex } & 0.007 & 0.021 \\
\hline & $(3.25)^{\star \star \star}$ & $(2.27)^{\star \star}$ \\
\hline \multirow[t]{2}{*}{ share_collective } & 0.008 & 0.050 \\
\hline & $(1.16)$ & $(1.52)$ \\
\hline \multirow[t]{2}{*}{ share_legal_person } & 0.005 & -0.008 \\
\hline & $(1.69)^{*}$ & $(0.58)$ \\
\hline \multirow[t]{2}{*}{ share_individual } & -0.001 & -0.032 \\
\hline & $(0.34)$ & $(3.16)^{\star \star \star}$ \\
\hline \multirow[t]{2}{*}{ share_foreign } & -0.002 & 0.076 \\
\hline & $(0.17)$ & $(2.03)^{\star \star}$ \\
\hline \multirow[t]{2}{*}{ Staying_CEO } & 0.004 & -0.014 \\
\hline & $(2.23)^{\star *}$ & $(1.33)$ \\
\hline \multirow[t]{2}{*}{ CEO_by_govt } & -0.009 & 0.006 \\
\hline & $(3.40)^{\star \star \star}$ & $(0.52)$ \\
\hline \multirow[t]{2}{*}{ 1share_1vote } & 0.003 & 0.048 \\
\hline & (1.59) & $(4.69)^{\star \star \star}$ \\
\hline \multirow[t]{2}{*}{$D_{O-B}$} & -0.008 & -0.025 \\
\hline & $(3.13)^{\star \star \star}$ & $(2.49)^{\star *}$ \\
\hline \multirow[t]{2}{*}{ Constant } & -0.003 & 0.038 \\
\hline & $(0.54)$ & $(1.67)^{\star}$ \\
\hline Observations & 884 & 881 \\
\hline R-squared & 0.07 & \\
\hline $\begin{array}{l}\text { Hansen's J test: } \\
\text { significance level }\end{array}$ & & 0.783 \\
\hline
\end{tabular}

Note. *, **, and *** represent statistical significance at the 10,5 , and 1 percent levels respectively. In the parentheses are t-statistics.

All variables except $\ln L_{t-1}$ and leverage $e_{t-1}$ are considered endogenous in the GMM specifications. For each endogenous variable (say R), the instruments are the size-industry mean of $\mathrm{R}$, and the mean of $\mathrm{R}$ for particular type of government agency in charge of the ownership reform. Industry dummies are not included in both specifications because they were tested to be jointly insignificant. 
Table 3. Determinants of Firm Performance (ROA): By organization Type

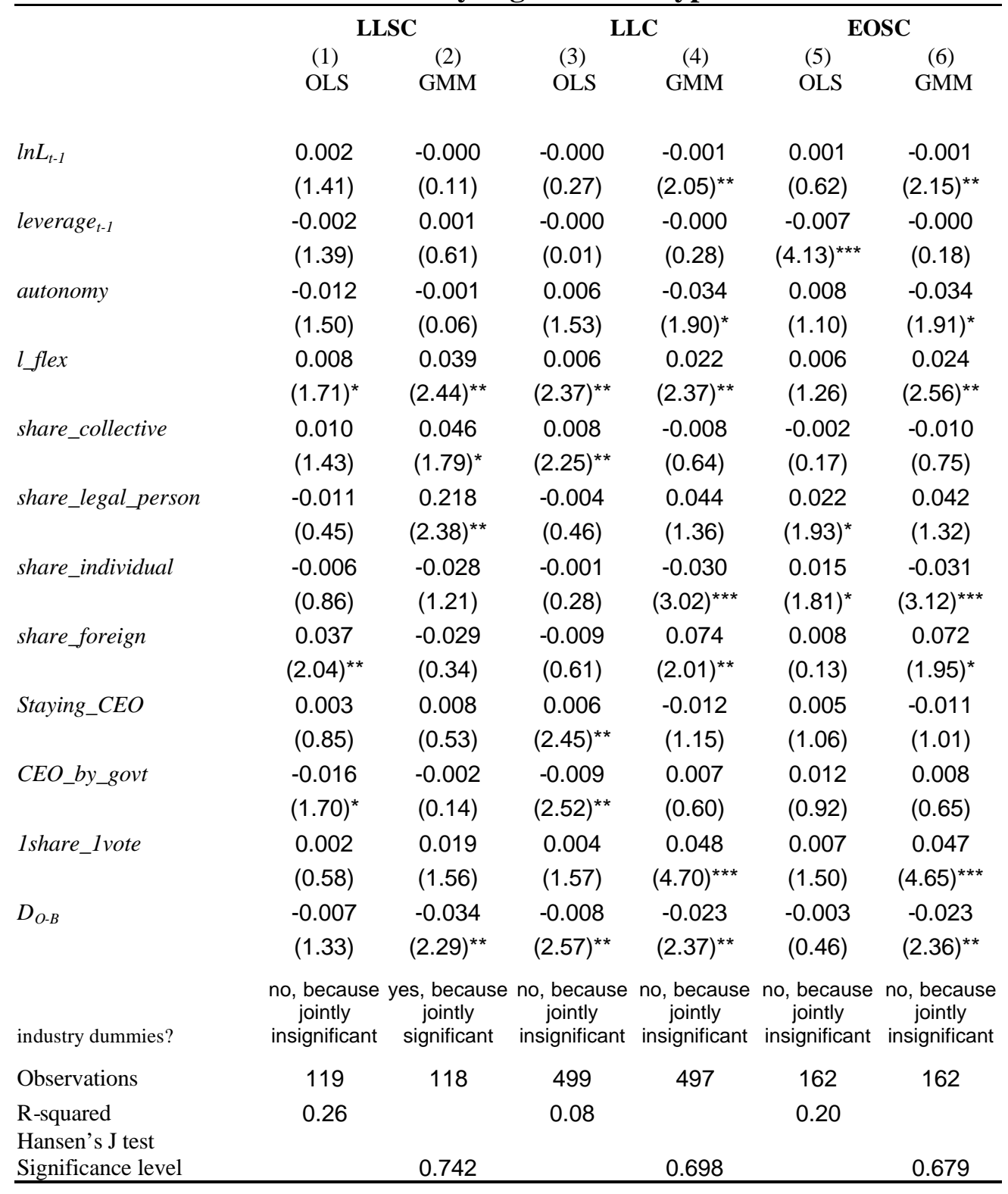

Note. **, **, and *** represent statistical significance at the 10,5 , and 1 percent levels respectively. In the parentheses are t-statistics. The constant is not reported

All variables except $\ln L_{t-1}$ and leverage $_{t-1}$ are considered endogenous in the GMM specifications. For each endogenous variable (say R), the instruments are the size-industry mean of $\mathrm{R}$, and the mean of $\mathrm{R}$ for particular type of government agency in charge of the ownership reform. 